\title{
Pulmonary fibrotic-like changes on follow-up chest CT exam in patients recovering from COVID-19 pneumonia
}

\author{
Ahmet VURAL(ID) \\ Ahmet Nedim \\ KAHRAMAN $($ ID)
}

Clinic of Radiology, University of Health Science Fatih Sultan Mehmet Training and Research Hospital, Istanbul, Turkey

Sağlık Bilimleri Üniversitesi Fatih Sultan Mehmet Ĕgitim ve

Araştırma Hastanesi, Radyoloji Kliniği, Istanbul, Türkiye
Cite this article as: Vural A, Kahraman AN. Pulmonary fibrotic-like changes on follow-up chest $C T$ exam in patients recovering from COVID-19 pneumonia. Tuberk Toraks 2021;69(4):492-498.

\section{Yazışma Adresi (Address for Correspondence)}

\section{Dr. Ahmet VURAL}

Clinic of Radiology, University of Health Science Fatih Sultan Mehmet Training and Research Hospital ISTANBUL - TURKEY

e-mail: vuralahmet@gmail.com

CCopyright 2021 by Tuberculosis and Thorax.

Available on-line at www.tuberktoraks.org.com

\begin{abstract}
Pulmonary fibrotic-like changes on follow-up chest CT exam in patients recovering from COVID-19 pneumonia

Introduction: To date, there is limited data on the long-term changes in the lungs of patients recovering from coronavirus (COVID-19) pneumonia. In order to evaluate pulmonary sequelae, it was planned to investigate fibrotic changes observed as sequelae in lung tissue in 3-6-month control thorax computerized tomography (CT) scans of moderate-to-severe COVID-19 pneumonia survivors.
\end{abstract}

Materials and Methods: $A$ total of 84 patients (mean age: 67.3 years \pm 15 ) with moderate-to-severe pneumonia on chest tomography at the time of diagnosis were included in the study, of which 51 (61\%) were males and $33(39 \%)$ were females. Initial and follow-up CT scans averaged 8.3 days \pm 2.2 and 112.1 days \pm 14.6 after symptom onset, respectively. Participants were recorded in two groups as those with and without fibrotic-like changes such as traction bronchiectasis, fibrotic - parenchymal bands, honeycomb appearance according to 3-6 months follow-up CT scans. Differences between the groups were evaluated with a two-sampled t-test. Logistic regression analyzes were performed to determine independent predictive factors of fibrotic-like sequelae changes.

Results: On follow-up CTs, fibrotic-like changes were observed in 29 (35\%) of the 84 participants (Group 1), while the remaining 55 (65\%) showed complete radiological recovery (Group 2). With logistic regression analysis, hospital stay of 22 days or longer (OR: 4.9; 95\% Cl: 20,32; $p<0.05$ ) and a CT score of 15 or more at diagnosis (OR: $2.2 ; 95 \% \mathrm{Cl}: 13.5,18 ; p<0.05)$ were found to be an independent predictor for sequelae fibrotic changes in lung tissue.

Conclusion: More than one-third of patients who survived COVID-19 pneumonia had fibrotic-like sequelae changes in the lung parenchyma. These changes were found to be associated with the presence of severe pneumonia at the time of diagnosis and longer hospital stay.

Key words: COVID-19; pneumonia; pulmonary fibrosis; CT scanning 


\section{Öz}

\section{COVID-19 pnömonisi geçiren hastalarda takip tomografisinde akciğer parankiminde izlenen fibrotik değişiklikler}

Giriş: Koronavirüs (COVID-19) pnömonisi geçirip iyileşen hastalarda, uzun vadeli akciğer değişiklikleri hakkında çok az şey bilinmektedir. Pulmoner sekelleri değerlendirmek amacıyla orta-şiddetli COVID-19 pnömonisinden kurtulanların, 3-6 aylık kontrol Toraks bilgisayarlı tomografilerinde (BT), akciğer dokusunda sekel olarak izlenen fibrotik değişiklikleri araştırmayı planladık.

Materyal ve Metod: Tanı anında akciğer tomografilerinde orta-ileri derecede pnömoni bulunan toplam 84 hasta çalışmaya dahil edilmiş olup 51'i (\%61) erkek, 33'ü kadın (\%39) hasta idi. Ortalama yaşları 67,3 yıl \pm 15,2 olarak hesaplandı. ilk ve takip BT taramaları semptom başlangıcından sonra sırasıyla ortalama 8,3 gün $\pm 2,2$ ve 112,1 gün \pm 14,6 olarak elde edildi. Katılımcılar, 3-6 aylık takip BT taramalarına göre traksiyon bronșektazisi, fibrotik - parankimal bantlar, bal peteği görünümü gibi sekel değişiklikleri olanlar ve olmayanlar şeklinde iki grup olarak kayıt altına alındı. Gruplar arası farklılıklar iki örneklemli t testi ile değerlendirildi. Fibrotik sekel değişikliklerin bağımsız tahmin faktörlerini belirlemek için lojistik regresyon analizleri yapıldı.

Bulgular: Takip BT'lerinde, 84 katılımcının 29'unda (\%35) (Grup 1) fibrotik sekel değişiklikler gözlenirken, kalan 55 katılımcı (\% 65) tam radyolojik iyileşme gösterdi (Grup 2). Lojistik regresyon analizi ile 22 gün veya daha uzun süre hastanede kalış süresi (OR: 4,9; 95\% CI: 20, 32; $p<0,05)$ ve tanı anında 15 veya daha fazla BT skoru (OR: 2,2; $95 \%$ CI: 13,5, 18; p<0,05) bulunması akciğer dokusunda sekel fibrotik değişiklikler için bağımsız prediktör olarak bulunmuştur.

Sonuç: COVID-19 pnömonisinden kurtulan hastaların üçte birinden fazlasında akciğer parankiminde fibrotik sekel değişiklikler görüldü. Bu değişikliklerin; tanı anında şiddetli pnömoni varlığı ve daha uzun hastanede kalış süresi ile ilişkili olduğu görüldü.

Anahtar kelimeler: COVID-19; pnömoni; pulmoner fibrozis; bilgisayarlı tomografi

\section{INTRODUCTION}

In January 2020, a novel coronavirus, SARS-CoV-2, was identified as the cause of the viral pneumonia outbreak in Wuhan, China. This disease, later named coronavirus disease 2019 (COVID-19), quickly spread globally. COVID-19 may exhibit serious respiratory complications (1). Patients may experience fever, cough, abdominal pain, and diarrhea. With the COVID-19 epidemic we face, many studies have been carried out describing pneumonia findings associated with COVID-19 from various parts of the world. Pathology studies have shown that, similar to other coronavirus infections (Severe acute respiratory syndrome - SARS and Middle East respiratory syndrome - MERS), COVID-19 also effects multiple organs and tissues in the body $(2,3)$. Although early findings are well defined, late findings and permanent changes are still not fully understood.

Thorax CT plays a very important role in the diagnosis and follow-up of patients with COVID-19 pneumonia. Numerous studies have described mild to severe radiological findings during the acute phase of COVID-19 (4-7). Liu et al. have reported that 53\% of patients with mild COVID-19 pneumonia completely disappeared in the lungs within 3 weeks after discharge (8). On the other hand, recent publications have shown that a significant proportion of hospitalized patients develop persistent pulmonary parenchymal changes which are seen on CT scans performed at discharge $(9,10)$. Since there is information that there may be permanent lung damage in patients who have recovered from previous coronavirus infections (SARS and MERS), it is possible to see permanent fibrotic changes after COVID-19 pneumonia (11-14). However, little is known about long-term lung changes following COVID-19 pneumonia. The aim of this study was to evaluate the changes observed in the lung in 3-6-month follow-up thorax CT scans and to investigate fibrosis-like changes and risk factors in the lung in patients recovering from moderate-to-severe COVID-19 pneumonia.

\section{MATERIALS and METHODS}

This retrospective study was approved by the scientific research committee established by the Ministry of Health for COVID-19 research. The study was carried out in accordance with the Declaration of Helsinki and was approved by the scientific studies and ethics committee of our institution (FSMEAHKAEK-2020/104). Patients treated and discharged from our institution due to moderate or severe COVID-19 pneumonia between 01 April 2020 and 31 August 2020 were evaluated retrospectively. Patients who came back to our institution for follow-up thorax CT examination within 3- to 6-months after discharge were included in the study. As inclusion criteria, confirmed positivity with ReverseTranscriptase Polymerase Chain Reaction (RT-PCR) test results for SARS-CoV-2 during hospitalization was sought. RT-PCR was performed on samples from nasopharyngeal swabs. Additional samples from sputum or bronchoalveolar lavage were used when necessary. Any positive result was classified as a con- 


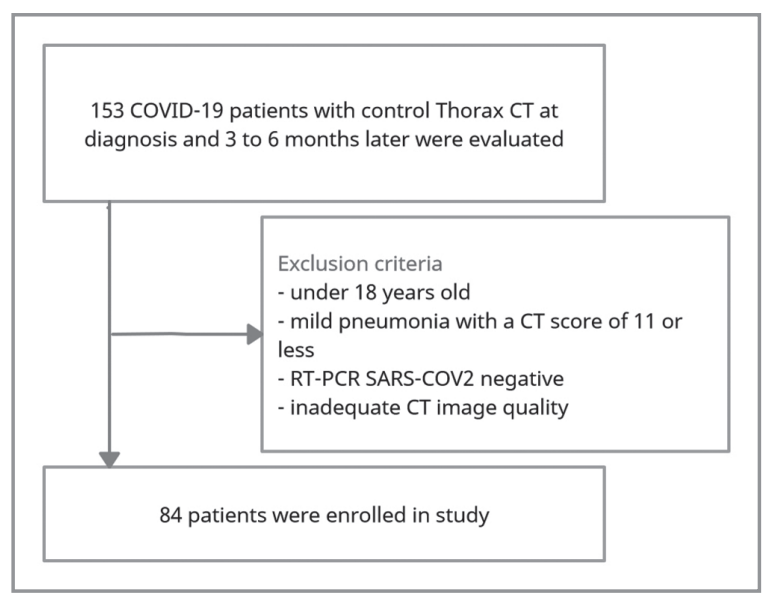

Figure 1. COHORT diagram of the study.

firmed COVID-19 infection (15). Diagnostic criteria in the guideline published by the World Health Organization for adults with COVID-19 pneumonia were used (16). Discharge criteria were made in accordance with the "COVID-19 adult patient management and treatment" guideline published by the Ministry of Health of the Republic of Turkey (17). The flow chart of the study planning and participant selection is shown in Figure 1.

For each participant, medical records, age, sex, length of hospital stay, and control thoracic tomography at the time of diagnosis and after 3-6 months were reviewed. Thoracic CT obtained at admission as each participant's first CT scans were evaluated. Patients with thoracic CT scans 3 to 6 months after the initial CT scans of these patients were included in the study.

Thoracic CT examinations were performed with the patient in supine position with a 128-slice CT device (GE Healthcare Optima CT660, USA). Examinations were performed from the thoracic entrance to the diaphragm without contrast agent administration. Low-dose thoracic CT examination was performed using an automatic exposure control system for tube flow. Images were reconstructed with $1 \mathrm{~mm}$ slice thickness and $1 \mathrm{~mm}$ spacing. Control CT examinations were also performed using the same device and the same parameters. All CT images were reviewed by two radiologists with 16 and 18 years of experience who were unaware of any clinical or laboratory findings. When evaluating follow-up CT examinations, the evaluation was made without looking at the first CT examination. Evaluation was made through our institution's image evaluation and archiving system (ExtremePACS; Ankara) using mediastinal window
(WL, $50 \mathrm{HU} ; \mathrm{WW}, 350 \mathrm{HU}$ ) and parenchyma window $(\mathrm{WL}, 600 \mathrm{HU}$; WW, $1500 \mathrm{HU}$ ) settings. According to the Fleischner Society Glossary, for each patient with pneumonia; Ground-glass opacities (GGO), consolidation, reticulation, emphysema, thickening of adjacent pleura, pleural effusion, nodule, masses, honeycomb appearance, bronchiectasis, and pleural shrinkage were evaluated as positive findings (18). Traction bronchiectasis, subpleural reticulation, parenchymal bands $(10,19)$ and/or honeycomb appearance (18) were accepted as evidence of sequela fibrotic-like change in control examinations.

A semi-quantitative scoring system was used to measure the abnormalities detected in the lung parenchyma (20). For each of the five lung lobes, no finding was scored as 0 , less than $5 \%$ involvement as 1 , $5 \%-25 \%$ involvement as $2,26 \%-49 \%$ involvement as 3, $50 \%-75 \%$ involvement as 4 , and more than $75 \%$ involvement 5 , and the sum of the scores of the 5 lobes was not included in the evaluation.

\section{Statistical Analysis}

While evaluating the findings obtained in the study, IBM SPSS Statistics 22 (IBM SPSS, Turkey) program was used for statistical analysis. While evaluating study data, conformity of the parameters to normal distribution was evaluated with the Shapiro Wilks test and found to be in accordance with the normal distribution. While evaluating study data, besides descriptive statistical methods (mean, standard deviation, frequency), continuous variables were evaluated using a two-sample t-test, respectively. Logistic regression analyzes were performed to determine independent predictive factors of fibrotic-like changes. Significance was evaluated at $\mathrm{P}<.05$ level.

\section{RESULTS}

Eighty-four patients (51 males (61\%), 33 females $(39 \%)$ who were hospitalized in our institution due to COVID-19 pneumonia diagnosis (ICD code J12. 82), who had moderate-to-severe pneumonia on lung tomography at the time of diagnosis, and had a Thorax CT examination within 3 to 6 months from the diagnosis were included in the study. Mean age was calculated as 67.3 (15.2) years. Initial and follow-up CT scans were obtained at a mean of 8.3 (2.2) days and 112.1 (14.6) days after symptom onset, respectively. Participants were recorded in two groups as those with and without sequelae fibrotic-like changes such as traction bronchiectasis, subpleural reticulation, fibrotic - parenchymal bands, honey- 
comb appearance according to 3-6-month follow-up CT scans (Figure 2). On follow-up CTs, fibrotic-like changes were observed in 29 (35\%) of 84 participants (Group 1), while the remaining 55 (65\%) showed complete radiological recovery (Group 2). Mean age of the patients with sequelae was 66.1 (13.5) years, and mean age of the patients without sequelae was 67.9 (16.2) years. There was no significant difference in age between the groups. Mean D-dimer values measured during hospitalization were 1603 (916) in the group with sequelae and 1716 (884) in the group without sequelae, and no significant difference was found between the groups.

Mean initial CT scores for the group with sequelae were 14.3 (2.5), the first CT scores for the group without sequelae were found to be 12.1 (1.2), and the first CT scores for the group with sequelae were statistically significantly higher (Figure 3 ).

Mean hospital stay of the group with sequelae was

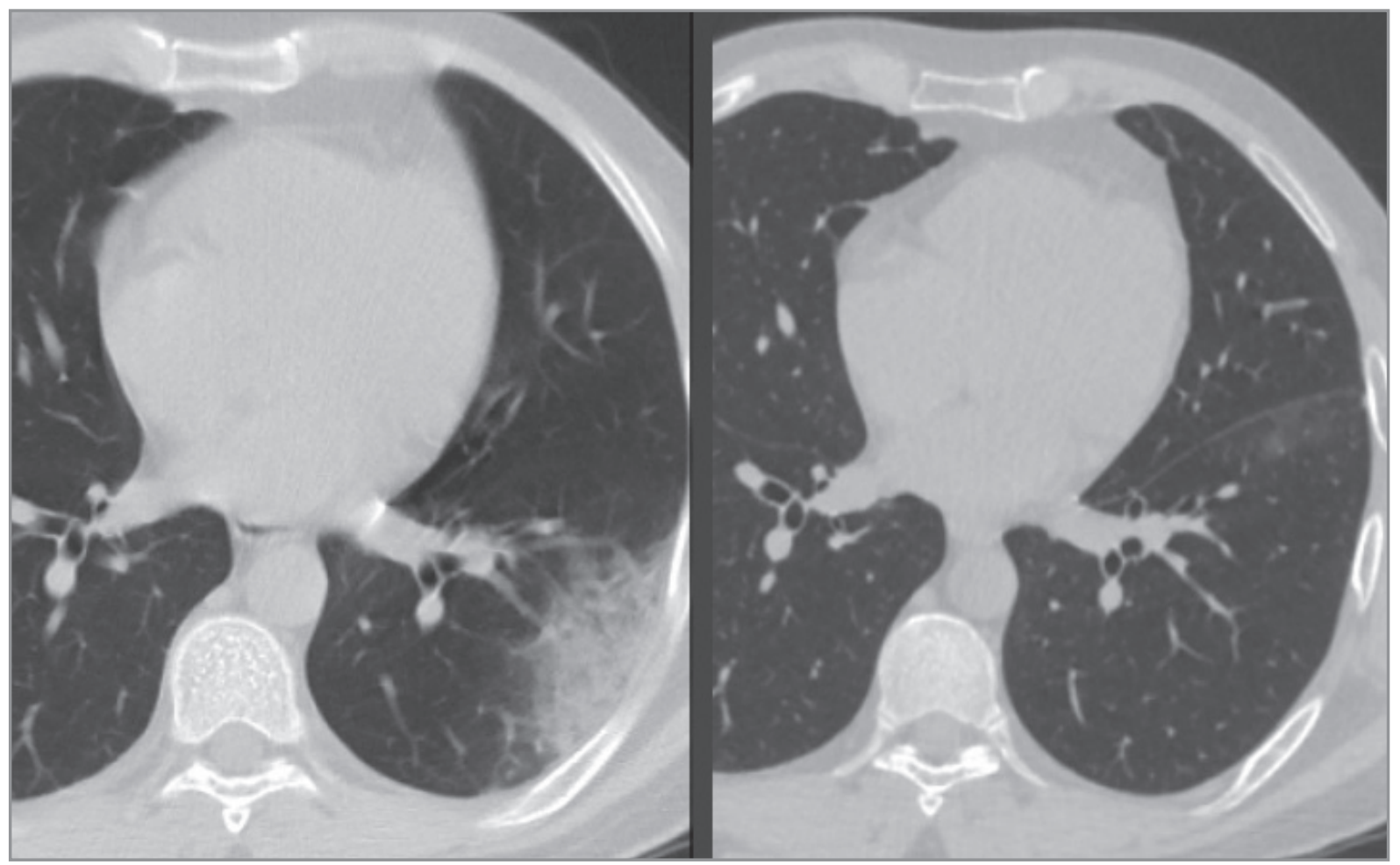

Figure 2. Consolidation in the left lower lobe in the first CT examination, and sequela ground glass opacity in the left lower lobe on control CT examination.

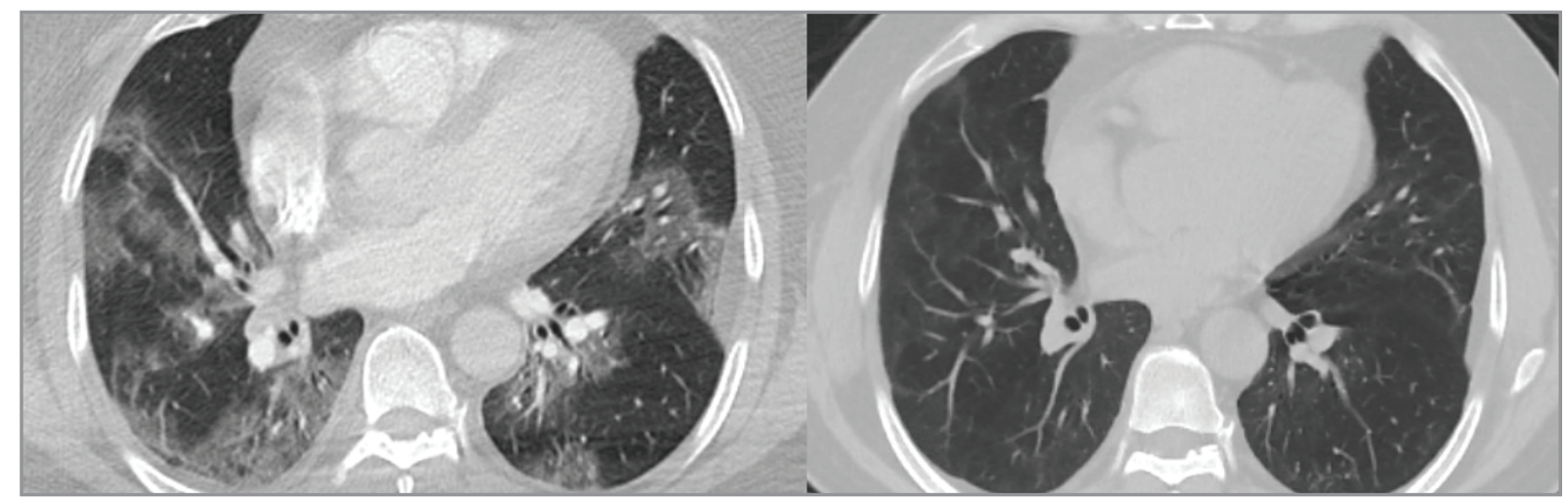

Figure 3. Diffuse ground glass opacities, pleural thickening and consolidation areas in both lungs at the time of diagnosis. In control examination, sequelae fibrotic densities, pleural focal thickening and weak ground glass opacities are observed. 
Table 1. Comparison of demographic and clinical characteristics

\begin{tabular}{|c|c|c|c|c|}
\hline & Group 1 & Group 2 & & \\
\hline & $\begin{array}{c}\text { Fibrosis-like changes } \\
\text { (Sequelae) Present }\end{array}$ & No Sequelae & $\mathbf{p}$ & Total \\
\hline Number $(n, \%)$ & $29(\% 35)$ & $55(\% 65)$ & & 84 \\
\hline Mean age* & $62.7 \pm 11.8$ & $65.4 \pm 13.4$ & 0.213 & $64.5 \pm 12.9$ \\
\hline Male & $60.17 \pm 10.1$ & $64.1 \pm 11.3$ & 0.116 & $62.7 \pm 1.5$ \\
\hline Female & $66.1 \pm 13.5$ & $67.9 \pm 16.2$ & 0.411 & $67.3 \pm 2.6$ \\
\hline \multicolumn{5}{|l|}{ Gender (n, \%) } \\
\hline Male & $18(\% 35)$ & $33(\% 65)$ & & $51(\% 61)$ \\
\hline Female & $11(\% 33)$ & $22(\% 67)$ & & $33(\% 39)$ \\
\hline Period between the onset of symptoms and first CT (days)* & $7.9 \pm 1.8$ & $8.5 \pm 2.3$ & 0.468 & $8.3 \pm 2.2$ \\
\hline Period between the onset of symptoms and control CT (days)* & $114.4 \pm 17$ & $110.9 \pm 13.3$ & 0.396 & $112.1 \pm 14.6$ \\
\hline D-dimer* & $1603 \pm 916$ & $1716 \pm 884$ & 0.584 & $1678 \pm 918$ \\
\hline First CT Score* & $14.3 \pm 2.5$ & $12.1 \pm 1.2$ & 0.001 & $12.9 \pm 2$ \\
\hline Duration of hospital stay (days)* & $23.7 \pm 2.6$ & $18.5 \pm 1.9$ & 0.001 & $20.4 \pm 3.3$ \\
\hline
\end{tabular}

23.7 (2.6), and mean of 18.5 (1.9) for the group without sequelae. Length of hospital stay of the group with sequelae was statistically significantly higher. With logistic regression analysis, a hospital stay of 22 days or longer (OR: 4.9; 95\% Cl: 20, 32; $\mathrm{p}<.05$ ) and a CT score of 15 or more at diagnosis (OR: 2.2; 95\% $\mathrm{Cl}: 13.5,18 ; \mathrm{p}<0.05)$ were found to be independent predictors for sequela fibrotic-like changes in lung tissue (Table 1).

\section{DISCUSSION}

In our study, fibrotic-like sequelae changes were detected in the lungs of 29/84 (35\%) patients who recovered from moderate-to-severe COVID-19 pneumonia when examined during a follow-up visit between 3 to 6 months after their discharge. With logistic regression analysis, a hospital stay of 22 days or longer (OR: 4.9; $95 \% \mathrm{Cl}: 20,32 ; \mathrm{p}<0.05)$ and a CT score of 15 or more at diagnosis (OR: 2.2; 95\% Cl: 13.5, 18; $\mathrm{p}<0.05)$ were found to be independent predictors for future fibrotic-like changes of the lung tissue.

Fibrotic-like changes were observed in 7 of 8 patients who were hospitalized and recovered from acute respiratory distress syndrome (ARDS) in the hospital due to COVID-19. ARDS seems to be a risk factor for fibrotic-like changes in the lung parenchyma. Previous studies have reported that a significant proportion of patients who survived ARDS may develop progressive fibrotic changes on CT scans $(21,22)$. However, it remains unclear whether the fibrosis-like changes detected in this study after COVID-19 pneumonia are permanent true fibrotic lung disease. Long-term studies will be decisive in this regard. In addition, it is known that mechanical ventilation applied to some of the patients during COVID-19 pneumonia is also a risk factor for fibrotic-like changes. Our inability to evaluate the frequency and duration of mechanical ventilation can be considered as one of the limitations of our study. Previously published data has reported that the application of mechanical ventilation is strongly associated with the fibrotic changes observed in ARDS cases (22). Similarly, sequelae of fibrotic-like changes in the lung in some of our patients may be associated with mechanical ventilator-induced lung injury. High D-dimer and C-reactive protein levels were observed in patients with COVID-19 pneumonia (23). In addition, increased coagulopathy and severe inflammatory response have been reported in severe COVID-19 patients (24). These findings are related to the severity of the disease and may also be associated with greater damage to the lung parenchyma.

We found that a higher CT score $(\geq 15)$ at the patients' initial CT examination was an independent prognostic factor for fibrotic-like changes in control examinations 3-6 months later. In a previous study, it was reported that the degree of fibrosis in the pathological samples of patients with idiopathic pulmonary fibrosis increased as the score increased in terms of prevalence in CT examination (25). In addition, a recent publication has revealed an association between a CT score of 18 or higher at diagnosis and an increased risk of mortality in patients with COVID-19 pneumonia (26). Thus, greater lung injury in the acute phase may be associated with a higher mortality rate in survivors and more severe pulmonary sequelae. 
There are studies that mention pulmonary diffusion abnormalities with sequela changes in the lung parenchyma at 6 months follow-up in patients with COVID19 pneumonia (14). Therefore, both structural and functional lung disorders can occur simultaneously in patients who survive severe COVID-19 pneumonia. The most common finding on lung CT scans of patients with COVID-19 pneumonia is ground-glass opacity (GGO). In addition, loss of consolidation and attenuation are common findings. Two studies describing early control CT findings reported that GGO and partial consolidation findings may continue to be seen as prolonged $(11,27)$. An increased prolongation or consolidation of GGO on follow-up CT of COVID-19 pneumonia described in these two studies may indicate a gradual regression of inflammation and reopening of the alveoli. GGO observed in the acute period of COVID-19 pneumonia may represent inflammatory infiltrates, edema or bleeding $(2,3)$. In addition, increased D-dimer levels detected in patients in the acute period may be associated with pulmonary embolism in COVID-19 patients. Thus, it may be responsible for some of the GGO and consolidations observed in the thorax CT of patients $(28,29)$. The underlying pathophysiology of GGO, which is frequently observed in COVID-19 pneumonia, and its correlation with fibrosis seem to be worth investigating with larger and long-term studies.

Other limitations of our study may be summarized as follows. First of all, the sample size was small and the examinations performed between 3 and 6 months were evaluated as follow-up examinations. We think that this period is short and a longer follow-up is required in order to determine whether the fibrotic-like changes are permanent. In fact, we think that long-term and multiple control thorax CT-containing groups can provide valuable information to determine whether these changes are permanent, progressive, or reversible. Secondly, although acute pneumonia period and control CT findings are defined in the lungs of the patients, it is not possible to know whether the findings that we describe as sequelae fibrotic changes were present before COVID-19 pneumonia. Third, a comparison of intra- and inter-rater consistency of CT evaluations was not made. Finally, the absence of a histological correlation is a limitation. Further studies are needed to investigate whether fibrotic-like changes on CT scans represent true pathological fibrosis.
In summary, control CT scans obtained within 3 to 6 months of disease onset showed fibrotic-like changes in the lung in more than one-third of patients who survived moderate-to-severe COVID-19 pneumonia. These patients were older and had more severe pneumonia in the acute phase. However, the long-term lung sequelae are still largely unknown. We believe that new, prospective, large-scale, long-term studies analyzing high-risk patients after COVID-19 pneumonia are necessary and will provide valuable information.

As a result, in this study, pulmonary fibrosis-like changes were observed in more than one-third of the participants with moderate-to-severe COVID-19 pneumonia during follow-up thorax tomography performed 3 to 6 months after the hospital discharge. For this reason, it will be useful to follow-up patients who have recovered from COVID-19 pneumonia in terms of pulmonary sequelae.

Ethical Committee Approval: This study approval was obtained from Health Sciences University Fatih Sultan Mehmet Training and Research Hospital Clinical Researches Ethical Committee (Decision No: 2020/135, Date: 24.09.2020).

\section{CONFLICT of INTEREST}

The authors declare that they have no conflict of interest.

\section{AUTHORSHIP CONTRIBUTIONS}

Concept/Design: AV, ANK

Analysis/Interpretation: AV, ANK

Data Acqusition: AV, ANK

Writing: AV, ANK

Clinical Revision: AV, ANK

Final Approval: AV, ANK

\section{REFERENCES}

1. World Health Organization (WHO). Coronavirus disease 2019 (COVID-19) Situation report. https://covid19.who. int/. Accessed 23 March 2021.

2. Liu J, Zheng $X$, Tong $Q$, Li W, Wang B, Sutter $K$, et al. Overlapping and discrete aspects of the pathology and pathogenesis of the emerging human pathogenic coronaviruses SARS-CoV, MERSCoV, and 2019-nCoV. I Med Virol 2020; 92(5): 491-4

3. Xu Z, Shi L, Wang Y, Zhang J, Huang L, Zhang C, et al. Pathological findings of COVID-19 associated with acute respiratory distress syndrome. Lancet Respir Med 2020; 8(4): 420-2. 
4. Bandirali $M$, Sconfienza $L M$, Serra $R$, Brembilla $R$, Albano $D$, Pregliasco FE, et al. Chest Radiograph Findings in Asymptomatic and Minimally Symptomatic Quarantined Patients in Codogno, Italy during COVID-19 Pandemic. Radiology 2020; 295(3): E7.

5. Pan F, Ye T, Sun P, Gui S, Liang B, Li L, et al. Time Course of Lung Changes at Chest CT during Recovery from Coronavirus Disease 2019 (COVID-19). Radiology 2020; 295(3): 715-21

6. $X u Y H$, Dong $J H, A n W M, L v X Y$, Yin $X P$, Zhang $J Z$, et al. Clinical and computed tomographic imaging features of novel coronavirus pneumonia caused by SARS-CoV-2. I Infect 2020; 80(4): 394-400.

7. Shi H, Han X, Jiang N, Cao Y, Alwalid O, Gu J, et al. Radiological findings from 81 patients with COVID-19 pneumonia in Wuhan, China: a descriptive study. Lancet Infect Dis 2020; 20(4): 425-34.

8. Liu D, Zhang W, Pan F, Li L, Yang L, Zheng D, et al. The pulmonary sequalae in discharged patients with COVID19: a short-term observational study. Respir Res 2020; 21(1): 125 .

9. Wang Y, Dong C, Hu Y, Li C, Ren Q, Zhang X, et al. Temporal Changes of CT Findings in 90 Patients with COVID-19 Pneumonia: A Longitudinal Study. Radiology 2020; 296(2): E55-E64.

10. Han $X$, Cao $Y$, Jiang $N$, Chen $Y, A$ Awalid $O$, Zhang $X$, et al. Novel Coronavirus Disease 2019 (COVID-19) Pneumonia Progression Course in 17 Discharged Patients: Comparison of Clinical and Thin-Section Computed Tomography Features During Recovery. Clin Infect Dis 2020; 71(15): 723-31.

11. Das KM, Lee $E Y$, Singh $R$, Enani MA, Al Dossari K, Van Gorkom $K$, et al. Follow-up chest radiographic findings in patients with MERS-CoV after recovery. Indian I Radiol Imaging 2017; 27(3): 342-9.

12. Antonio GE, Wong KT, Hui DS, Wu A, Lee N, Yuen EH, et al. Thin-section $C T$ in patients with severe acute respiratory syndrome following hospital discharge: preliminary experience. Radiology 2003; 228(3): 810-5.

13. Zhang P, Li J, Liu H, Han N, Ju J, Kou Y, et al. Long-term bone and lung consequences associated with hospitalacquired severe acute respiratory syndrome: a 15-year follow-up from a prospective cohort study. Bone Res 2020; 8: 34 .

14. Han X, Fan Y, Alwalid O, Li N, Jia X, Yuan $M$, et al. Sixmonth Follow-up Chest CT Findings after Severe COVID19 Pneumonia. Radiology 2021; 299(1): E177-E186.

15. Huang C, Wang Y, Li X, Ren L, Zhao J, Hu Y, et al. Clinical features of patients infected with 2019 novel coronavirus in Wuhan, China. Lancet 2020; 395(10223): 497-506.

16. World Health Organization (WHO). Clinical management of severe acute respiratory infection when novel coronavirus (nCoV) infection is suspected: interim guidance. https://www.who.int/docs/default-source/coronaviruse/ clinical-management-ofnovel-cov.pdf Published January 12, 2020. Accessed March 23, 2021.
17. TC Sağlık Bakanlığı Halk Sağlığı Müdürlüğü, COVID-19 (SARS-CoV-2 Enfeksiyonu) Erişkin Hasta Yönetimi ve Tedavisi 2021 (Turkish). Available from: https://covid19. saglik.gov.tr/Eklenti/40719/0/covid-19rehberieriskinhastayonetimivetedavipdf.pdf Accessed: May 20, 2021.

18. Hansell DM, Bankier AA, MacMahon H, McLoud TC, Müller NL, Remy J. Fleischner Society: glossary of terms for thoracic imaging. Radiology 2008; 246(3): 697-722.

19. Westcott IL, Cole SR. Traction bronchiectasis in end-stage pulmonary fibrosis. Radiology 1986; 161(3): 665-9.

20. Chang YC, Yu CJ, Chang SC, Galvin JR, Liu HM, Hsiao CH, et al. Pulmonary sequelae in convalescent patients after severe acute respiratory syndrome: evaluation with thinsection CT. Radiology 2005; 236(3): 1067-75.

21. Meduri GU, Headley S, Kohler G, Stentz F, Tolley E, Umberger $R$, et al. Persistent elevation of inflammatory cytokines predicts a poor outcome in ARDS. Plasma IL-1 beta and IL-6 levels are consistent and efficient predictors of outcome over time. Chest 1995; 107(4): 1062-73.

22. Desai SR, Wells AU, Rubens MB, Evans TW, Hansell DM. Acute respiratory distress syndrome: $C T$ abnormalities at long-term follow-up. Radiology 1999; 210(1): 29-35.

23. Helms J, Tacquard C, Severac F, Leonard-Lorant I, Ohana $M$, Delabranche $X$, et al. High risk of thrombosis in patients with severe SARS-CoV-2 infection: a multicenter prospective cohort study. Intensive Care Med 2020; 46(6): 108998.

24. George PM, Wells AU, Jenkins RG. Pulmonary fibrosis and COVID-19: the potential role for antifibrotic therapy. Lancet Respir Med 2020; 8(8): 807-15.

25. Kazerooni EA, Martinez FJ, Flint A, Jamadar DA, Gross BH, Spizarny DL, et al. Thin-section CT obtained at 10-mm increments versus limited three-level thin-section CT for idiopathic pulmonary fibrosis: correlation with pathologic scoring. AJR Am / Roentgenol 1997; 169(4): 977-83.

26. Francone $M$, lafrate $F$, Masci GM, Coco S, Cilia F, Manganaro L, et al. Chest CT score in COVID-19 patients: correlation with disease severity and short-term prognosis. Eur Radiol 2020; 30(12): 6808-17.

27. Pan Y, Guan H, Zhou S, Wang Y, Li Q, Zhu T, et al. Initial $C T$ findings and temporal changes in patients with the novel coronavirus pneumonia (2019-nCoV): a study of 63 patients in Wuhan, China. Eur Radiol 2020; 30(6): 3306-9.

28. Thoma P, Rondelet B, Mélot $C$, Tack D, Naeije $R$, Gevenois $P A$. Acute pulmonary embolism: relationships between ground-glass opacification at thin-section CT and hemodynamics in pigs. Radiology 2009; 250(3): 721-9.

29. Oudkerk M, Büller HR, Kuijpers D, van Es N, Oudkerk SF, McLoud T, et al. Diagnosis, Prevention, and Treatment of Thromboembolic Complications in COVID-19: Report of the National Institute for Public Health of the Netherlands. Radiology 2020; 297(1): E216-E222. 